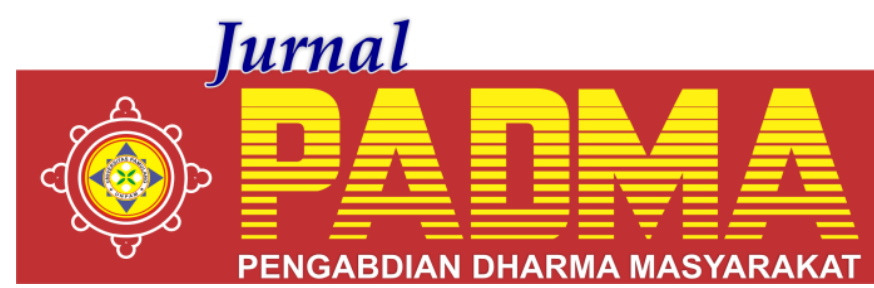

VOLUME 1, NOMOR 4, OKTOBER 2021

\title{
PENDIDIKAN LITERASI KEUANGAN PADA ANAK YANG BERHADAPAN DENGAN HUKUM DI LEMBAGA PEMBINAAN KHUSUS ANAK KELAS II JAKARTA
}

\author{
1Imas Masriah, ${ }^{2}$ Surya Budiman, ${ }^{3 *}$ Desy Mulat Asri, ${ }^{4}$ Eni Sumarsih, ${ }^{5}$ Jefri Tangkas \\ Budianto, ${ }^{6}$ Ririn Maryanti, ${ }^{7}$ Wahyu Maida \\ Universitas Pamulang, Tangerang Selatan, Banten, Indonesia \\ *desy9910000918@gmail.com
}

\begin{abstract}
Abstrak
Pengabdian ini berjudul Pendidikan Literasi Keuangan Pada Anak Yang Berhadapan Dengan Hukum Di Lembaga Pembinaan Khusus Anak Kelas II Jakarta. Mengedukasi bagaimana pentingnya pendidikan literasi keuangan pada anak yang berhadapan dengan hukum di LPKA Kelas II Jakarta, bagaiamana penerapan nilai literasi keuangan yang efektif bagi Anak Didik Pemasyarakatan di LPKA Kelas II Jakarta dan peran serta keluarga untuk menanamkan nilai pendidikan literasi keuangan ini bagi Anak Didik Pemasyarakatan di LPKA Kelas II Jakarta. Metode yang digunakan berupa penyuluhan yang dilanjutkan dengan pemberian kuesioner tentang pemahaman pengelolaan keuangan keluarga, serta wawancara.
\end{abstract}

Kata Kunci: Manajemen, Literasi Keuangan Pada Anak, Pengelolaan Keuangan

\section{Abstract}

This service is entitled Financial Literacy Education for Children in Conflict with the Law at the Special Class II Children's Development Institute, Jakarta. Educate on the importance of financial literacy education for children who are in conflict with the law at LPKA Class II Jakarta, how to apply effective financial literacy values for Correctional Students at LPKA Class II Jakarta and the role of families to instill the value of financial literacy education for Correctional Students in LPKA Class II Jakarta. The method used in the form of counseling followed by the provision of questionnaires about the understanding of family financial management, as well as interviews.

Keywords: Management; Financial Literacy in Children; Financial Management

\section{PENDAHULUAN}

Kondisi keuangan yang berbeda pada setiap keluarga tidak hanya sebatas kemampuan untuk mendapatkan sumber pendapatan yang cukup namun juga kemampuan untuk mengelola keuangan tersebut dengan bijak dan tepat. Muara dari pengelolaan yaitu untuk menentukan tingkat kesejahteraan keluarga. Kesulitan keuangan keluarga biasanya berawal dari pengetahuan keuangan yang tidak memadai serta berhubungan dengan kesehatan keluarga secara fisik dan psikologis. Faktor eksternal sebagai dampak dari krisis ekonomi secara global sangat mempengaruhi kondisi ekonomi keluarga. Perlu kemampuan pengelolaan keuangan yang baik dalam penerapan kehidupan sehari-hari. Kemampuan pengelolaan keuangan dimaksud untuk mempersiapkan keuangan keluarga di waktu yang akan datang. Aktivitas ekonomi masyarakat dalam hal konsumsi sehari-hari dengan melakukan pembelian yang didasarkan pada keinginan atau kesukaan tanpa adanya perencanaan yang mempertimbangkan manfaat dan kegunaan.

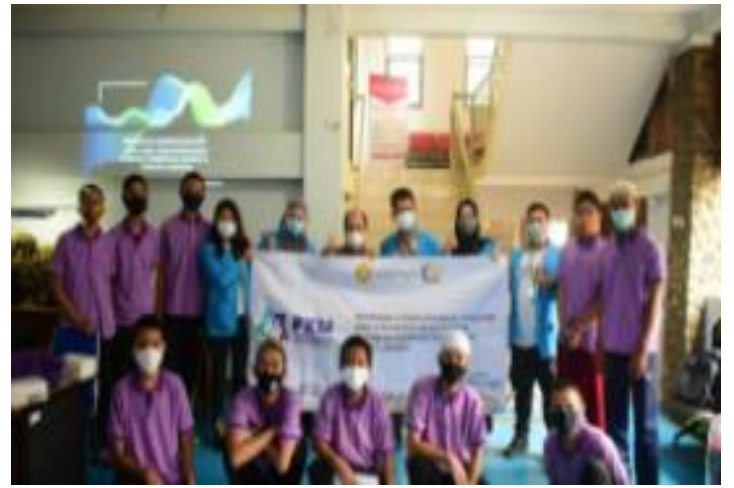

Gambar 1. Foto Bersama Narasumber 


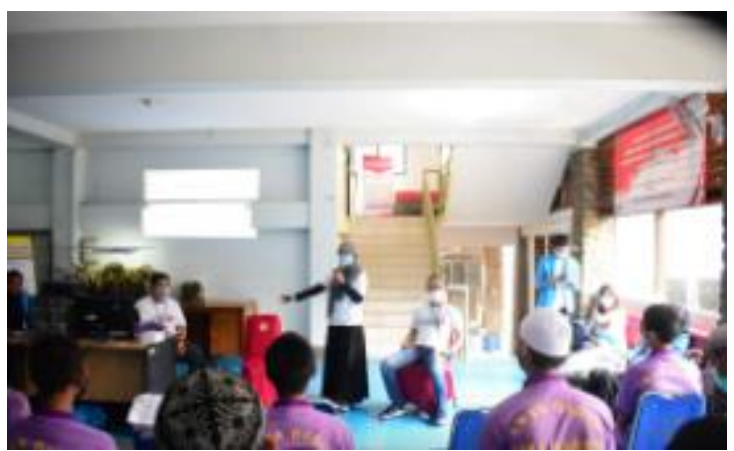

Gambar 2. Pelatihan dengan peserta

\section{Metode Kegiatan}

Melihat permasalahan yang dihadapi maka langkah-langkah yang dilakukan untuk mencapai tujuan dan sasaran kegiatan ini adalah diadakan pendekatan kepada instansi terkait yaitu LPKA kelas II Jakarta melalui sosialisasi serta pelatihan berupa penjelasan tujuan pendidikan literasi keuangan pada anak yang berhadapan dengan hukum dalam upaya dan strategi mewujudkan peserta didik yang melek ekonomi dan memberikan wawasan dalam pentingnya literasi keuangan sejak dini. Pengabdian Kepada Masyarakat (PKM) akan dilaksanakan di Lembaga Pembinaan Khusus Anak kelas II Jakarta, Jl. Raya Gandul Cinere pada tanggal 19 Januari 2021. Pelaksanaan kegiatan ini akan dibimbing oleh tim pelaksana staf-staf pengajar dari Universitas Pamulang dengan mengikut sertakan peran instansi terkait baik petugas maupun peserta didik LPKA kelas II Jakarta.

Metode pelatihan yang diterapkan berdasarkan solusi atas permasalahan di LPKA kelas II Jakarta Pengabdian Kepada Masyarakat (PKM) akan dilaksanakan di LPKA kelas II Jakarta, Jl. Raya Gandul Cinere pada tanggal 19 Januari 2021, sebagai berikut :

\section{Metode Pelatihan}

Pelatihan yang dirancang untuk mengembangkan sumber daya manusia melalui rangkaian kegiatan identifikasi, pengkajian serta proses belajar yang terencana. Untuk mengatasi permasalahan yang ada, tim akan melakukan sosialisasi bagi seluruh peserta didik, termasuk petugas LPKA kelas II Jakarta tentang pendidikan literasi keuangan pada anak yang berhadapan dengan hukum. Adapun metode pelatihannya sebagai berikut :

1. Pengumpulan data, dengan memberikan kuisioner atau wawancara kepada peserta didik dan petugas LPKA kelas II Jakarta.

2. Pelatihan manajemen, dengan memberikan penyuluhan atau sosialisasi kepada peserta didik dan petugas LPKA kelas II Jakarta.

\section{HASIL DAN PEMBAHASAN}

Literasi dapat diartikan sebagai proses sosial yang dibangun. Proses literasi berfokus pada pembelajaran interaksi antara orang dewasa (apakah orangtua di rumah atau guru di kelas) dan siswa. Pendidikan literasi keuangan dapat diartikan sebagai sebuah pemahaman yang komprehensif serta mendalam tentang pengelolaan keuangan pribadi ataupun keluarga yang membuat seseorang mempunyai kuasa, pemahaman dan keyakinan penuh terhadap keputusan keuangan yang diambil. Seperti yang diungkapakan oleh Vitt et al (2000) mendefinisikan.

Menurut OECD (2005) pendidikan keuangan diartikan sebagai proses membangun kemampuan yang mana konsumen atau pun investor memperbaiki pemahaman tentang produk-produk serta konsep keuangan melalui informasi, instruksi dan nasihat untuk meng embangkan keahlian serta kepercayaan diri dan kesadaran terhadap risiko keuangan serta meningkatkan peluang membuat keputusan keuangan yang cerdas, mengetahui kemana sebaiknya meminta bantuan keuangan, dan mampu membuat tindakan akternatif untuk meningkat kesejahteraan.. Hal itu sejalan dengan pendapat Mason \& Wilson (dalam Krisna, et.al, 2010) yang menyatakan literasi keuangan adalah kemampuan seseorang untuk mendapatkan, memahami, dan mengevaluasi informasi yang relevan untuk pengambilan keputusan dengan memahami konsekuensi finansial yang ditimbulkannya. Maka dari itu begitu pentingnya pendidikan literasi keuangan diajarkan kepada seseorang sedini dan sebaik mungkin.

Pengetahuan literasi keuangan merupakan bagian dari pengetahuan 
keuangan itu sendiri. Literasi keuangan mempunyai esensi yang lebih mendetail dibandingkan dengan pengetahuan keuangan secara umum. Huston (2010) menyatakan bahwa pengetahuan finansial merupakan dimensi yang tidak terpisahkan dari literasi keuangan, namun belum dapat menggambarkan literasi keuangan seseorang.

\section{PENUTUP}

\section{KESIMPULAN}

1. Mengingat pentingnya pemberian intervensi mengenai literasi keuangan pada anak akan sangat berpengaruh terhadap tingkat kesejahteraan di masa yang akan datang maka penerapan pendidikan literasi keuangan secara optimal harus segera dilakukan sedini mungkin. Penanaman nilai - nilai literasi keuangan yang benar pada usia dini akan selalu memberkas dalam fikiran mereka. Pemahaman dasar mengenai pendidikan literasi keuangan pada anak akan menjadikan anak tumbuh dewasa dengan bekal menganai literasi keuangan yang cukup serta mempunyai fondasi yang kuat untuk memahami

2. Keterbukaan dan pemberian ruang diskusi yang cukup pada anak dalam membahas mengenai urusan finansial mutlak diperlukan agar anak tidak hanya menjadi obyek yang pasif tentang urusan finasial mereka.

3. Peran tempat didik anak juga sangat penting untuk menanamkan nilai - nilai pendidika literasi keuangan pada anak, dalam hal ini LPKA Kelas II Jakarta merupakan lingkungan paling berpengarus bagi para peserta didik dalam penerapan literasi keuangan pada anak didik yang berhadapan dengan hukum.

\section{SARAN}

1. Mengadakan Pengabdian Kepada Masyarakat Lanjutan perlu dilakukan pendampingan oleh petugas terhadap penerapan nilai literasi pada anak didik LPKA Kelas II Jakarta.

2. Pada Pengabdian Kepada Masyarakat selanjutnya akan diadakan prakik langsung dalam pengelolaan keuangan bagi anak didik LPKA Kelas II Jakarta.
3. Pada Pengabdian Masyarakat selanjutnya akan dilakukan pendampingan dalam penerapan nilainilai literasi pada anak.

\section{DAFTAR PUSTAKA}

Alhabeeb, M. J. 1999. Allowances and the economic socialization of children. Association for Financial Counseling and Planning Education, 10 (2): 1 - 9.

Allen, M. W., Edwards, R., Hayhoe, C. R., \& Leach, L. 2007. Imagined interaction, attitudes towards money and credit, and family coalitions. Journal of Family and Economic Issues, 28: 3 22.

Astuti, D E. (2013). Perilaku Konsumtif Dalam Membeli Barang Pada Ibu Rumah Tangga Di Kota Samarinda. eJournal Psikologi, 1(2), 2013 : 148 156.

Bernheim, D. B., Garrett, D.M., \& Maki, D. M. 2001. Education and saving: The longterm effects of high school financial curriculum mandates. Journal of Public Economics, 80 (3): 435-465.

Bowen, C. F. 2002. Financial Knowledge Of Teens And Their Parents. Financial Counseling and Planning Volume 13(2): 202

Chatib Munif.2012. Gurunya Manusia.Bandung:Mizan.

Chen, H., \& Volpe, R. P. 1998. An analysis of personal financial literacy among college students. Financial Services Review, 7(2): 107 - 128.

Clarke et al,2005.The acquisition of family financial roles an responsibilities. Family and Consumer Science Research Journal,33:321-340.

Clarke, M. D., Heaton, M. B., Israelsen, C. L., \& Eggett, D. L. 2005. The acquisition of family financial roles and responsibilities. Family and Consumer Sciences Research Journal, 33: 321 340.

Cohen, S., \& Xiao, J.1992. Consumer socialization: Children and money. Childhood Education, 69 (1): 43-44.

Danes, S. M. 1994. Parental perceptions of children's financial socialization. Financial Counseling and Planning, 5: $127-146$. 
Eka, P. D., et al. (2020). Manajemen Keuangan Untuk Meningkatkan Perekonomian Keluarga Kampung Serua Poncol Tangerang Selatan. BAKTIMAS: Jurnal Pengabdian pada Masyarakat, 2(2), 109-113.

Nurhayati, N., et al. (2020). Pemberdayaan Pengelolaan Keuangan Dalam Meningkatkan Kemampuan Manajerial Bagi Pelaku Usaha Di Desa Warnasari Kecamatan Pangalengan Kabupaten Bandung. KAIBON ABHINAYA: JURNAL PENGABDIAN MASYARAKAT, 2(2), 66-70.

Pratidhina,C.G.2018.Implementasi pembelajaran literasi dalam mata pelajaran sejarah indonesia di SMA Negeri 11 Yogyakarta. Universitas Sanata Dharma. Yogyakarta.Skripsi

Rapih Subroto,2016. Pendidikan Literasi Keuangan Pada Anak: Mengapa dan bagaimana?.Scholaria.Vol.6 No.2,Mei 2016;14-28.

Sabri, M. F. MacDonald, M. Hira, T. K. \& Masud, J. 2010. Childhood Consumer Experience And Fianancial Literacy of Students in Malaysia. Familiy And Consumer Sciences Research Journal 38 (4).

Saul, K. E. 1997. Money matters: Exploring money concepts with young children. Dimensions of Early Childhood, 25 (2): $17-21$
Seefeldt, Carol., et al. 2010. Social Studies For The Preschool/Primary Child. 8th Edition.New York: Pearson.

Sefeldt et al ,2010.Social Studies For The Preschool/Primary Child.8th Edition. New York:Pearson.

Sina, P G. 2014. Peran Orangtua Dalam Mendidik Keuangan Pada Anak (Kajian Pustaka). Ragam Jurnal Pengembangan Humaniora 14 (1): 7486.

Suiter, M., \& Meszaros, B. 2005. Teaching about saving and investing in the elementary and middle school grades. Social Education, 69 (2): 92-95

Vitt, L. A., Anderson, C., Kent, J., Lyter, D. M., Siegenthaler, J. K., \& Ward, J. 2000. Personal Finance And The Rush To Competence: Financial Literacy Education In The U.S. Middleburg, VA: Fannie Mae Foundation.

Xiao, J. J., Noring, F. E., \& Anderson, J. G. 1995. College students' attitudes towards credit cards. Journal of Consumer Studies and Home Economics, 19: 155 - 174.

Yunus Abidin,2015. Pembelajaran Multiliterasi (Sebuah jawaban atas tantangan Pendidikan abad ke-21 dalam konteks keindonesiaan). Bandung:Refika Aditama. 